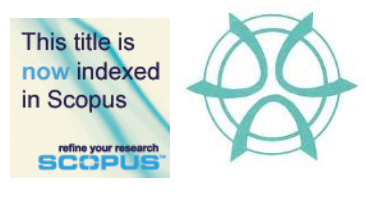

PLANNING MALAYSIA:

Journal of the Malaysian Institute of Planners

VOLUME 16 ISSUE 2 (2018), Page 21 - 29

\title{
METALS IN RESPIRABLE AND INHALABLE DUST AT EDUCATIONAL INSTITUTIONS
}

\author{
Shamzani Affendy Mohd Din ${ }^{1}$, Nik Nurul-Hidayah Nik Yahya ${ }^{2} \&$ \\ Rashidi Othman ${ }^{3}$ \\ ${ }^{1,3}$ Kulliyyah of Architecture and Environmental Design \\ INTERNATIONAL ISLAMIC UNIVERSITY MALAYSIA \\ ${ }^{2}$ Faculty of Engineering and Green Technology \\ UNIVERSITI TUNKU ABDUL RAHMAN, MALAYSIA
}

\begin{abstract}
Haze episode has always becomes the one of the common reasons for emergency closing of school. Unique approach had been used to collect and examine the toxic metal of the respirable and inhalable dust by combining the latest personal cyclone and seven-hole head sampler together with the latest spectrometer of inductively coupled plasma-mass spectrometry (ICP-MS) in a single framework. Iron is found significantly different with the highest concentration at $107.895 \mathrm{ng}$ $\mathrm{m}^{-3}$. The mean ranges of metal in respirable dust found in educational institutions are between 0.005 and $78.629 \mathrm{ng} \mathrm{m}^{-3}$. The findings of this research seen the amount of respirable dust exceeds more than 21.13 per cent than inhalable dust. Analysed metals found are not exceeding the ambient air exposure limit established by Department of Environment Malaysia. Hence, it is understood that the outdoor atmospheric environments of Malaysian educational institutions are non-hazardous for both visitors and occupiers (students and personnel). The high level of iron signify that it is safe for the crossing of children to have a traffic light in front of the school, but the idling of motor vehicles emitted more pollutant that risks health of the school children, teachers and officers. These suggest that when there are schools, there shall be constructed of flyover crossing for long term solution or with certain distance to traffic sources.
\end{abstract}

Keywords: inhalable dust, respirable dust, educational institution, human health, metal exposure. 
Shamzani Affendy Mohd Din, Nik Nurul-Hidayah Nik Yahya \& Rashidi Othman

Metals in Respirable and Inhalable Dust at Educational Institutions

\section{INTRODUCTION}

Assessments of heavy metals ( $\mathrm{Cr}, \mathrm{Cu}, \mathrm{Fe}, \mathrm{Mn}, \mathrm{Ni}, \mathrm{Pb}, \mathrm{V}$ and $\mathrm{Zn}$ ) were determined on particle concentrations at Gombak, Selangor. For the purpose of this study, a public college and a boarding school were selected. The two selected educational institutions are the Sekolah Integrasi Gombak (SIG) and Kolej Vokasional Gombak (KVG). The assessment of this type of built environment is significant as the precondition of education is a healthy educational institution microenvironment. However, several studies show that the classrooms and its surrounding area are hazardous.

This research aims at assessing the metal content of airborne particulates from outdoor of the educational institutions and its effect towards human health. Its objectives are to determine metal concentration contributed by the multisources surrounding the educational institutions and to compare the respirable and inhalable dust, metal concentration, and effects of airborne particulates towards human health.

\section{AIRBORNE PARTICULATES IN EDUCATIONAL INSTITUTIONS}

The average age of children attending these educational institutions is from 13 to 18 years old, which could be classified under a risky group of people. Moreover, it is also found that in general views, Malaysian latest growth rate for the age between 0 and 14 years old and 15 and 64 years old are approximately at 7.799 and 20.501, respectively (Malaysia Statistical Department, 2015). Thus, indicating that the amounts of school children are increasing at a huge amount each year and most of the population are the school age children. As found by previous studies, the amount of time spend with the children in a school are approximately $30 \%$ and from 80 to $90 \%$ per day (Tofful \& Perrino, 2015; Che, Frey, \& Lau, 2015). The personal sampling against outdoor sampling also had been done through several studies (Branis, Rezacova, \& Domasova, 2005; Che et al., 2015; Roosebroeck et al., 2007; Zhu, Hinds, Kim, \& Sioutas, 2011; Janssen, Hoek, Brunekreef, \& Harssema, 1999; Zhang et al., 2014). In comparison with other types of sampling, the results show high result in dust collected with personal sampler at the higher range of multiple concentrations.

The issue that widely arise in the assessment of children school environment are the traffic-related sources and its human health impact. Previous studies also show that the design of the roadways in support with the roadway element affect the movement of the vehicles that later causes the increase in concentration of the dust due to the vehicles activities and combustion of its energy (Zhu et al., 2011; Stridh, Andersson, Linder, Oscarsson, \& Bang, 2002; Ibrahim \& Ramli, 2009; Kulshrestha, Massey, Masih, \& Taneja, 2014). The vehicle movement of acceleration, deceleration and stopping due to the cycle of traffic signal at the junctions affects the combustion of fuel and thus, affect the level of the heavy metal in dust concentration (Ibrahim \& Ramli, 2009). During 
PLANNING MALAYSIA

Journal of the Malaysia Institute of Planners (2018)

peak hours, high capacities of vehicles are also believed to increase the iron (Fe) (Wahid et al., 2014), Ni and $\mathrm{Cr}$ (Kulshrestha et al., 2014) through the process of fuel combustion. These factors also largely contributed by the fuel type, vehicle type, utilization parameters and operating modes (Zhu et al., 2011).

The potential sources found in and surrounding the educational institutions based on previous research are crustal dust, indoor organic, movement of student, school personnel and paperwork, vehicle exhaust, traffic sources, industrial source, secondary inorganic components, the infiltration of outdoor air, inadequate construction characteristic of building, absence of automated air filtration system, building construction, inappropriate ventilation, use of cleaning products and procedures, resuspension of dust deposited indoors, soil-earth crust erosion, secondary reactions in atmosphere, high no. of person, high activity, ventilation system and location in the city (Branis et al., 2011; Tofful \& Perrino, 2015; Zhang et al., 2014; Stridh et al., 2002). Moreover, the association between the teaching organisation that traffic-related sources and the level of health of its occupant had been explored by several researchers. This is for the respirable dusts and inhalable dusts (Janssen et al., 1999), are widely exposed towards the children. Human health also can be affected due to the metal found in particles and (Janssen et al., 1999).

\section{MATERIALS AND METHOD}

Personal outdoor concentrations were collected for this study on the behaviour of the children, such as playing outdoors and hand-to-mouth contact contribute to exposure towards heavy metal pollution. This is also agreed by Branis (2005) that the empty classroom at night and during weekend found the $\mathrm{PM}_{10}$ concentrations were double than the indoor. Thus, indicating that outdoor personal exposure of an educational institution is significant to be monitored and assessed. Therefore, this research applied personal sampler in order to measure an individual personal exposure to airborne particles. There are two types of sampling head being used that are the cyclone and 7 hole sampling head. Both represent the respirable and inhalable dust accordingly.

These factors of time-weighted concentration at various micro environment that people spend their time show the exposure of the individual towards the inhalable and respirable dusts. However, for the purpose of this study, in order to standardize the exposure time between this built environment, the normal global working hours at 8-hours personal exposure were collected. This is also based on the standard of sampling hours as recommended by Deparment of Safety and Health Malaysia (DOSH).

There were 12 samples collected. All 12 samples were collected from outdoor ambient of the teaching organisations. This research adopts the mass spectrometry analysis to trace metal element in the airborne particles that was collected on the $0.8 \mu \mathrm{m}$ pore size membrane cellulose filter paper. The nine 
Shamzani Affendy Mohd Din, Nik Nurul-Hidayah Nik Yahya \& Rashidi Othman

Metals in Respirable and Inhalable Dust at Educational Institutions

inorganic elements analysed in this research are $\mathrm{Ba}, \mathrm{Cr}, \mathrm{Cu}, \mathrm{Fe}, \mathrm{Mn}, \mathrm{Ni}, \mathrm{Pb}, \mathrm{V}$, and $\mathrm{Zn}$. The metal concentrations are measured in SI unit of $\mathrm{mg} / \mathrm{m}^{3}$. The sampling was done at the outdoor ambient of SIG and KVG that located $720.39 \mathrm{~m}$ in distance to each other.

\section{RESULTS}

The following graphs are illustrated based on the means and standard deviation found from the samples collected from the two educational institutions at Gombak, Selangor. The concentrations of $\mathrm{V}, \mathrm{Cr}, \mathrm{Mn}, \mathrm{Fe}, \mathrm{Ni}, \mathrm{Cu}, \mathrm{Zn}$, and $\mathrm{Pb}$ value recorded dust at Sekolah Integrasi Gombak (SIG) and Kolej Vokasional Gombak $(\mathrm{KVG})$ in Gombak, Selangor were illustrated in graphs as in the Figure 1.

Iron that was collected from the inhalable dust at the KVG had the highest concentrations in all samples from the teaching organization. In addition, this analysis also demonstrated that the KVG inhalable dust were found highest in $\mathrm{Mn}, \mathrm{Fe}, \mathrm{Cu}$ and $\mathrm{Pb}$. The respirable result showed highest concentrations amount of $\mathrm{V}, \mathrm{Cr}$ and $\mathrm{Zn}$. The inhalable dusts at SIG were found highest in $\mathrm{Ni}$ and $\mathrm{Ba}$. These data are highlighted in blue, below.

These analyses also discovered that no significant metals were higher and lower than each other between the respirable and inhalable dust. The mean ranges of respirable dust found in educational institutions were between 0.005 and $78.629 \mathrm{ng} \mathrm{m}^{-3}$. The averages in inhalable dust were at 0.006 and $37.749 \mathrm{ng}$ $\mathrm{m}^{-3}$. Thus, sum up to an overall average for all metal concentrations at 0.005 and $89.207 \mathrm{ng} \mathrm{m}^{-3}$, for respirable and inhalable dust, accordingly. The dominant metal for all sampling locations at educational institutions was Fe. The highest was iron for both inhalable dust and respirable dust at 70.520 and $107.895 \mathrm{ng} \mathrm{m}^{-3}$, correspondingly. Thus, suggesting the amount of exceeded respirable dust towards the inhalable dust were at 21.13 per cent.

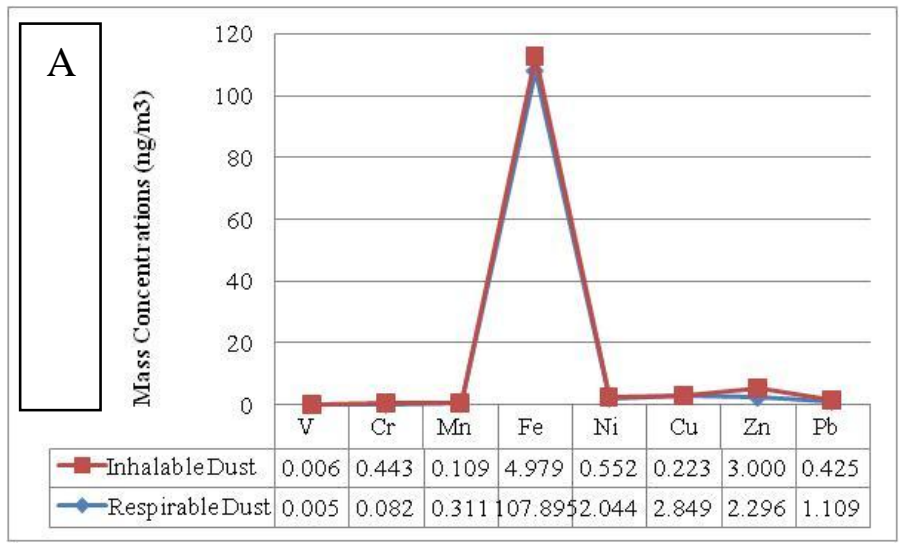


PLANNING MALAYSIA

Journal of the Malaysia Institute of Planners (2018)

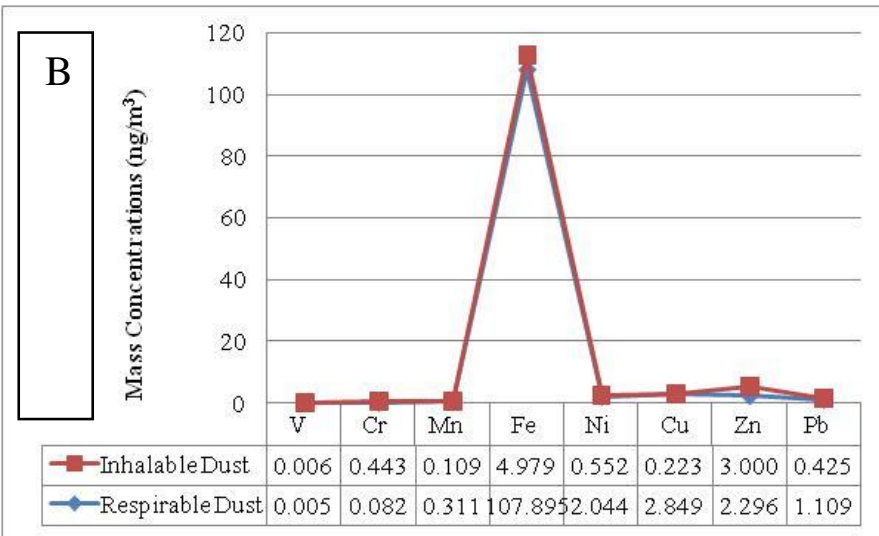

Figure 1: Heavy metal content in respirable and inhalable particulate matter at educational institutions in Gombak, Selangor.

Notes: A- SIG. B - KVG

\section{Observed Sources at the Educational Institutions}

The area that surround the sampling sites are acknowledged as its locality. Through the locality observation, several sources from nature and manmade activities were found. These are listed in the following Table 1.

Table 1: The primary and secondary reactions found in SIG and KVG locality.

\begin{tabular}{|l|l|l|}
\hline $\begin{array}{l}\text { Primary Natural } \\
\text { Sources }\end{array}$ & $\begin{array}{l}\text { Both SIG and KVG exposed to the greenery conserved forest, } \\
\text { limestone caves and hilly area, acid intrusive, lithosols types } \\
\text { of soils and shallow latosols are found on steep hilly land. }\end{array}$ \\
\hline \multirow{5}{*}{$\begin{array}{l}\text { Secondary Mandmade } \\
\text { Activities }\end{array}$} & $\begin{array}{l}\text { This included the roadway pavement; } \\
\text { railing; concrete kerbs; roof tiles, } \\
\text { concrete and steel from the bus stop; } \\
\text { roadway painting; steel and painting of } \\
\text { the signage; concrete, roof tiles and } \\
\text { paint from the nearby structure of post } \\
\text { guard; concrete wall; paint; school } \\
\text { concrete and steel gate; the steel and } \\
\text { removable canopies from the stall and } \\
\text { motor vehicles materials that are parked } \\
\text { at temporal period. }\end{array}$ \\
\cline { 2 - 3 } & $\begin{array}{l}\text { roadway pavement; railing; roadway } \\
\text { painting; concrete kerbs; roof tiles; } \\
\text { concrete wall; paint; steel, concrete, } \\
\text { electrical components and plastic wears } \\
\text { from the traffic light; steel, concrete, } \\
\text { roof tiles, paint and plastic wear from } \\
\text { the nearby structure of post guards and } \\
\text { shop lots; the steel and removable }\end{array}$ \\
\hline
\end{tabular}


Shamzani Affendy Mohd Din, Nik Nurul-Hidayah Nik Yahya \& Rashidi Othman Metals in Respirable and Inhalable Dust at Educational Institutions

\begin{tabular}{|l|l|l|}
\hline & $\begin{array}{l}\text { canopies from stall and motor vehicles } \\
\text { materials that are parked at temporal } \\
\text { period nearby the KVG and educational } \\
\text { schools. }\end{array}$ \\
\hline
\end{tabular}

This street is a busy way that lead to the nearby freeway. There are traffic lights in front of the schools and nearby the T-junctions. Thus, many vehicles have stopped in idling and waiting mode for a few minutes at the said traffic lights. Thus, indicates that this urban located educational institution contained a high concentration level of heavy metals as it was located nearby traffic lights ( $\mathrm{t}$ junctions and crossroads). In a perspective, it was safe for the crossing of children to have traffic light, but the idling mode by motor vehicles emitted more pollutant that risked health of the school children, teachers and officers. These suggested that when there are schools, there shall be construction of flyover crossing rather than the traffic light as the long term solution. It is to be highlighted that this layout of school was typical to the other schools in Malaysia.

The results suggested that the amount of idling motor vehicles is high in daily schools as the parents send and pick up their children at schools every morning, afternoon and evening. Thus, the children are exposed to traffic sources during most rush traffic hours in school. The human activities that occurred at both outdoor educational institutions were the movement of people to the nearby stall and shops. The cooking and smoking at the restaurants. People were transporting through these local streets nearby the teaching organisations from the universities surrounding houses area to the main road to city. In parallel with the above discussion, (Branis et al., 2005) stated that human activities are the changing agent of the undisturbed soils. In this case, the heterogeneous dust was formed and became road dust. For Malaysia, a hot and humid country, the earth crust is believed to dry (Ghosh, 2014). Hence resuspension of airborne particles occurs due to the human activities, mainly transportations in these sites.

\section{Respirable \& Inhalable Dust at Educational Institutions}

The above sources proved that the fine particles came from the combustion of motor vehicles, combustion of energy from cooking process and the dispersions through the wear breaks and tires of the motor vehicles; damage the road elements and building structures. However, it is believed that most of the respirable dust found was emitted by the motor vehicle emissions. This is in agreement with Ghosh (2014), Latif, Othman and Johnny (2006), and Laden, Neas, Dockery and Schwartz (2000). In line with the discussion by Branis et al. (2005), the features of coarse particles easily settled, letting them deposited at rapid gravity force outdoor. This also indicated the complexity of the coarse particle found outdoor of the educational institutions as rapid coagulation occurred in high airborne particle numbers causing the increased particles. 
PLANNING MALAYSIA

Journal of the Malaysia Institute of Planners (2018)

In addition, iron metal elements contributed by both coarse and fine particles in soil (Che et al., 2015; Salam, Hossain, Siddique, \& Shafiqul Alam, 2008) were believed to occur both in respirable and inhalable dust fraction. Even though different types of particles were dominant by different chemical elements, the results shows a similar trend between both. Thus, suggested that both results were from similar sources. The above summaries of results showed that the metal contents found in respirable and inhalable dusts were varying. It was found that the mean concentrations ranged of respirable dust value were lower than the inhalable dust. The natural environment of lithosols type of soil and acid intrusive rocks, supporting this finding in Fe high concentration level that was found as a large contributor to the natural airborne particles. This is in agreement by previous researcher (Che et al., 2015; Wahid et al., 2014; Tahir, Suratman, Foo, Hamzah, \& Latif, 2013).

\section{Iron Dominant the Respirable and Inhalable Dust}

Both of the teaching organisations were located in the urban background, hence the high concentration value was relevant to the urban area as found by Tahir in Salam et al.(2008). Traffic emissions and soil entrainment that contributed to the formation of road dust at site were the potential sources of iron contamination in the dust samples. Therefore, the findings were supported by many scientists, that the Fe was found highest due to the industrial and traffic activities. Additionally, traffic emissions are further defined by Wahid et al. (2014), and Abbasi, Tufail and Chaudhry (2013), as the vehicular exhaust emission, non-engine combustion sources due to engine abrasion and clutch, break and tyres wear), and road infrastructure (corrosion of galvanized steel crash barriers, pavement wear). In this case, industrial source is to be omitted due to residential, commercials and educational institutions are the surrounding built environment of the area.

Furthermore, for ambient air in Malaysia, there are allowable exposure limit for lead, zinc and copper at $0.025 \mathrm{mg} \mathrm{m}^{3}, 0.1 \mathrm{mg} \mathrm{m}^{3}$ and $0.1 \mathrm{mg} \mathrm{m}^{3}$, respectively. From the above results, the percentage of exceeding limit had been calculated. These data summarised that none of them exceeded the limits.

In the calculation of mean summaries of highest metal according site and types of dust it was clearly indicated that the highest metal concentrations levels were found in samples collected from KVG, whilst the Fe were the only metals found highest in the SIG samples. This highly supported the above discussions of locality that the crossroads provide higher metal accumulations in KVG samples. Therefore, in designing future roadways, the engineers should be alerted that crossroads should be avoided if there were any educational institutions constructed at the area. 
Shamzani Affendy Mohd Din, Nik Nurul-Hidayah Nik Yahya \& Rashidi Othman

Metals in Respirable and Inhalable Dust at Educational Institutions

\section{CONCLUSION}

In conclusion, it is safer for the children crossing to have traffic light in front of the school. However the idling motor vehicles emitted pollutant that risked health of the school children, teachers and officers. Hence suggesting that there should be flyover crossing for long term solution or with certain distance to traffic sources.

\section{ACKNOWLEDGEMENT}

The author would like to acknowledge the FRGS grant by Ministry of Higher Education and the International Islamic University Malaysia for facility supports to make this research possible.

\section{REFERENCES}

Abbasi, M. N., Tufail, M. A., \& Chaudhry, M. M. (2013). Assessment of heavy elements in suspended dust along the Murree Highway near capital city of Pakistan. World Applied Science Journal, 21(9), 1266-1275.

Branis, M., Rezacova, P., \& Domasova, M. (2005). The effect of outdoor air and indoor human activity on mass concentrations of $\mathrm{PM}_{10}, \mathrm{PM}_{2.5}$, and $\mathrm{PM}_{1}$ in a classroom. Environmental Research, 99(2), 143-149.

Che, W. W., Frey, H. C., \& Lau, A. K. H. (2015). Comparison of sources of variability in school age children exposure to ambient $\mathrm{PM}_{2.5}$. Environmental Science\& Technology, 49(3), 1511-1520.

Ghosh, M. K. (2014). An analysis of roadside dust fall in Bhilai-3 of Durg District Chhattisgarh, Central India and its impact on human health. International Journal of Research in Environmental Science and Technology, 4(2), 54-60.

Janssen, N. A., Hoek, G., Brunekreef, B., \& Harssema, H. (1999). Mass concentration and elemental composition of $\mathrm{PM}_{10}$ in classrooms. Occupational and Environmental Medicine, 56(7), 482-487.

Kulshrestha, A., Massey, D. Masih, J., \& Taneja, A. (2014). Source characterization of trace elements in indoor environments at urban, rural and roadside sites in a semi-arid region of India. Aerosol and Air Quality Research, 14, 1738-1751.

Laden, F., Neas, L. M., Dockery, D. W., \& Schwartz, J. (2000). Association of Fine PM from different source with daily mortality in 6 US cities. Environmental Health Perspectives, 108(10), 941-947.

Talib, Latif, M. T., Othman, M. R., \& Johnny, Z. (2006). Kajian Kualiti Udara di Bandar Kajang, Selangor. The Malaysian Journal of Analytical Sciences, 10(2), 275284.

Malaysia Statistical Department (2015). Population Statistics - Population ('O00) by Age Group, $1891-2013$.

Roosebroeck, V. S., Jacobs, J., Janssen, N. A. H., Oldenwening, M., Hoek, G., \& Brunekreef, B. (2007). Long-term personal exposure to $\mathrm{PM}_{25}$, soot and $\mathrm{NOx}$ in 
children attending schools located near busy roads, a validation study. Atmospheric Environment, 41(16), 3381-3394.

Salam, A., Hossain, T., Siddique, M. N. A., \& Shafiqul Alam, A. M. (2008). Characteristics of atmospheric trace gases, particulate matter, and heavy metal pollution in Dhaka, Bangladesh. Air Quality Atmospheric Health, 1, 101-109.

Stridh, G., Andersson, H., Linder, B., Oscarsson, J., \& Bang, C. S. (2002). Total dust exposure and size distribution of airborne particles in day-care centres. In Proceedings of Indoor Air 2002: Schools And Offices (pp. 97-102).

Tahir, N. M., Suratman, S., Foo, T. F., Hamzah, M. S., \& Latif, M. T. (2013). Temporal distribution and chemical characterization of atmospheric particulate matter in the eastern coast of Peninsular Malaysia. Aerosol and Air Quality Research, 13(2), 584-595.

Tofful, L., \& Perrino, C. (2015). Chemical composition of indoor and outdoor PM2.5 in three schools in the City of Rome. Atmosphere, 6(10), 1422-1443.

Ibrahim, W. H. W., \& Ramli, N. A. (2009). Human settlement development: A case study of mitigating air pollution emissions at traffic light junctions. In S. Sassen (Ed.), Human settlement development (Vol. 2) (pp. 35-55). Oxford: Eolss Co.

Wahid, N. B. A., Latif, M. T., Suan, L. S., Domminick, D., Sahani, M., Jaafar, S. A., \& Mohd Tahir, N. (2014). Source identification of PM in semi-urban area of Malaysia using multi-variate techniques. Bulletin of Environmental Contamination and Toxicology, 92(3), 317-322.

Zhu, Y., Hinds, W. C., Kim, S., \& Sioutas, C. (2011). Concentration and size distribution of ultrafine particles near a major highway. Journal of the Air \& Waste management Association, 52(9), 1032-1042. https://doi.org/10.1080/10473289.2002.10470842

Zhang, N., Han, B., He, F., Xu, J., Niu, C., Zhou, J.,...\& Xu H. (2014).

Characterization, health risk of heavy metals, and source apportionment of atmospheric $\mathrm{PM}_{2.5}$ to children in summer and winter: an exposure panel study in Tianjin, China. Air Quality Atmospheric Health, 8(4), 347-357.. 